\title{
Midwest Logging Firm Perspectives: Harvesting on Increasingly Parcelized Forestlands
}

\author{
Shorna Allred, ${ }^{1}$ Charles Michler, ${ }^{2}$ and Cortney Mycroft ${ }^{3}$ \\ ${ }^{1}$ Department of Natural Resources, Cornell University, 209 Bruckner Hall, Ithaca, NY 14853, USA \\ ${ }^{2}$ Hardwood Tree Improvement and Regeneration Center, Department of Forestry and Natural Resources, \\ Purdue University, 715 W. State Street, West Lafayette, IN 47907, USA \\ ${ }^{3}$ Southwick Associates, P.O. Box 6435, Fernandina Beach, FL 32035, USA \\ Correspondence should be addressed to Shorna Allred, srb237@cornell.edu
}

Received 4 June 2011; Accepted 11 August 2011

Academic Editor: Guofan Shao

Copyright (C) 2011 Shorna Allred et al. This is an open access article distributed under the Creative Commons Attribution License, which permits unrestricted use, distribution, and reproduction in any medium, provided the original work is properly cited.

Loggers play a critical role in the sustainable production of wood and paper products, and harvesting activities contribute to economic health and viability of many Upper Midwest communities in the United States. If the logging sector is unable to procure wood efficiently and economically from an increasingly parcelized land base, the competitive ability of the forest industry could be jeopardized. Little is known about the functions of the logging sector related to the forest resource land base on which they depend, and it is imperative to improve our understanding of this important part of the forest industry. The purpose of this study was to determine prospective attitudes about the future of the logging industry and how trends in forestland parcelization and harvesting mechanization are impacting the logging industry, especially as it relates to smaller tracts of land.

\section{Introduction}

Logging firms are the intermediaries between private and publicly owned forest resources and the associated forest products industry. The forest industry depends on these small independent logging businesses which harvest timber and deliver roundwood and chips for processing and are responsible for nearly all commercial timber harvests that occur $[1,2]$. Through their harvesting activities, loggers shape the composition, health, and future development of forests. Thus, changes to the forest resource base on which loggers rely can have major impacts on the viability of this sector [1]. One factor affecting the resource base upon which loggers rely is forest parcelization which is defined as the "division or parcelization of larger, single ownership forest tracts into smaller parcels with diverse ownerships, many of which become more developed; and reduction in forest patch size, combined with isolation among patches" [3, page 54].

\section{Forestland Parcelization and Logging}

Forestland parcelization is related to logging in that the consequence is decreased tract sizes and an overall reduction in land available for harvesting. Researchers project that, by 2050, forestland approximately the size of the state of Pennsylvania will be consumed by urbanization in the United States [4]. In their study of private forest lands in the state of Georgia, Wear et al. [5] established that population density is a significant predictor of commercial timberland availability with the probability of commercial forestry approaching zero at 150 persons per square mile. Population density impacts commercial forest inventory through the conversion of timber growing area to residential or urban use and through the "perceived impermanence" of land use which discourages active investment by owners in timber production on their lands [5, page 108]. Utilizing USDA Forest Service Forest Inventory and Analysis data and a survey of timber buyers in the southeastern United States, Greene et al. [6] found that timberland in the smallest ownerships (less than 10 acres) rose by $7 \%$ while the amount of timberland in the $200+$ acreage ownerships declined nearly $16 \%$ [6] over a 6-year period between 1982 and 1989. In addition to forestland parcelization, ownership parcelization effects are also present with the average private forest landholding in Indiana decreasing from 22 to 16 acres during a 10 -year period from 1993 to 2003 [7]. 
What are the implications of forest resource parcelization on the logging industry? Researchers have noted the challenges associated with harvesting smaller parcels of forestland including issues related to costs of production [8-11]. With a trend toward decreasing forest tract sizes on private forestlands [12], harvesting costs increase due to higher moving and setup costs and higher hourly fixed costs [6]. As forest tract size harvested decreases, the cost per acre of treatment increases, especially for capital intensive mechanized harvesting methods $[6,13,14]$. The cost of production is increased due to diminished economies of scale $[13,15]$ and decreased investment in and completion of forest management activities by nonindustrial private forest owners (NIPF) [16, 17]. Logging in increasingly urbanized areas and on smaller tracts is also impacted by the rising number of logging regulations and ordinances at the local level $[10,18]$.

While forest parcelization is a trend that is external to the logging industry, an internal trend of relevance is also occurring. This trend is towards more highly productive mechanized harvesting systems that are capital intensive. Over 10 years ago, researchers predicted an increase in harvesting mechanization [19]. The trend toward increasingly mechanized harvesting technology is not necessarily compatible with harvesting smaller tract sizes [20]. Greene et al. [19] also agreed that smaller tracts will likely be harvested using less-mechanized systems due to cost. In Northern Minnesota, Sinclair et al. [1] examined 23 logging companies and found that less mechanized systems are less productive than more mechanized systems by between 0.11 and 0.34 cords per man-hour. A key conclusion of this study was that the risk involved with investing in higher levels of mechanization is not profitable in poor wood supply markets. Also, these researchers observed a prevalence of less mechanized operations in the felling and skidding of timber. Rickenbach and Steele [21] conducted a similar study of productivity with relation to mechanized and nonmechanized firms in Wisconsin. Their findings indicate that mechanized firms are more productive on an annual basis and obtain a higher percentage of their total harvest volume from state and county forests than nonmechanized firms. Conversely, nonmechanized firms utilized a higher percentage of their total stumpage source from nonindustrial private landowners. Countering the higher production of mechanized firms, nonmechanized firms are less threatened by parcelization as they have the potential of a competitive edge on smaller-scale harvests.

One cannot discuss the logging sector without also considering ownership of the land from which timber is harvested. Loggers obtain their supply of wood from both public and private lands, and over $75 \%$ of the eastern hardwood sawtimber is located on privately owned nonindustrial forest land [22]. Less than $10 \%$ of eastern hardwood sawtimber is on land owned by the timber industry [22]. In fact, the relationship between forest resource ownership and timber supply was illuminated by Rickenbach and Steele [21] when they introduced the concept of NIPF-dependency. In their study of logging firms operating in the Upper Peninsula of Michigan and northern Wisconsin, they found clear distinctions between firms that were dependent on wood from private lands versus those that were more diversified in the ownership of lands harvested. NIPF dependent firms harvested $88 \%$ of their stumpage from private forestlands, while non-NIPF-dependent logging firms harvested $43 \%$ of their timber from public lands, 33\% from industrial lands, and $24 \%$ from NIPF lands [21]. NIPF-dependent firms had fewer, smaller, and less intensively harvested sales and were more likely to harvest small tracts profitably indicating an adaptation of a subset of firms to the changes in the private forestland resource base. Similarly, Keefer et al. [23] found that some Pennsylvania logging firms were opting for lessmechanized systems that are ideal for harvesting smaller traces ( $\leq 19.77$ acres). Keefer et al.'s study hints to the fact that some logging firms are specializing in smaller less intensive harvesting. Further study is needed to determine if the trend is present in other regions, particularly those with less-forest ownership diversity.

\section{Loggers and Logging Firm Characteristics}

Researchers have examined characteristics of loggers and logging firms across the South [24], in West Virginia [25], and in Georgia [19]. Munn et al. [24] conducted a 1993-mail survey for the American Pulpwood Association (APA) and asked logyard and procurement managers questions regarding their log suppliers. Respondents reported an increase in production of cords per week in their 1993 survey when compared to a former survey the APA conducted in 1987 (no response rate reported). During this time, the type of cutter heads also had a noted change from shears to rotary and chainsaw heads. Loggers in West Virginia were surveyed by Luppold et al. [25] to examine obstacles facing productivity in the timber industry. Using responses received from $24 \%$ of the 1,230 loggers in their sample, Luppold et al. [25] compared the volume of large and small logging operations. The factors limiting the productivity of small firms were skidding and trucking, while the procurement activities of large firms were limited by the felling and skidding of timber. Both large and small firms attributed productivity barriers to regulations, taxes, and workman's compensation. Firms with higher productivity by volume tended to have more money invested in equipment than the smaller firms. In Georgia, independent loggers, identified by their subscription to a timber industry publication, were surveyed to identify their harvesting systems, transport methods and costs, and other factors affecting their firms [19]. Based on data from 32\% of the 769 independent loggers surveyed, Green et al. [19] were able to summarize the types of harvesting equipment used, products produced, and costs to move between tracts for independent loggers in Georgia. Researchers in this study calculated the capital invested by deriving a depreciated value of equipment using age and make supplied in the survey. They concluded that different harvest systems were more costly to move to new tracts than others. Also, manual felling was less productive per man-hour than a mechanized system, but less capital was invested. They also concluded that mechanization will increase in the future but that smaller 
tracts will be harvested using less-mechanized systems due to cost [19].

While much research has been conducted, questions remain as to whether and how increased parcelization of forests will impact the logging industry. This study will examine this harvesting on increasingly parcelized lands from the perspective of independent logging firms operating in the north central region of the US. This study focuses on industry outlook by examining perceptions of logging companies toward external and internal challenges and trends facing the logging industry. Perceptions related to the future of the logging industry relate specifically to the challenges and trends discussed above such as forest parcelization and implications for parcel size harvested and profitability as well the issues related to level of mechanization and profitability identified in the literature. Of particular importance are the critical trends identified for timber supply on increasingly fragmented private lands as well as the trends toward mechanization which favor larger-scale harvests in terms of efficiency. The specific research questions this study aims to answer are as follow.

(1) What are logging firm views on external and internal challenges and trends facing the logging industry?

(2) How do parcel size and source of timber (ownership) relate to timber sale profitability?

(3) How do parcel size and mechanization relate to timber sale profitability?

\section{Methods}

This study focuses on the north central region of the United States. The majority of timberland in this region is owned by nonindustrial private landowners (62\%), industrial landowners (33\%), and public landowners (5\%) [26]. Utilization of wood harvested for products in the north central region is 1.6 billion cubic feet annually, of which $31 \%$ is sawlogs, $31 \%$ is pulpwood, $22 \%$ is fuelwood, $12 \%$ is composites, $2 \%$ are other products, and $1 \%$ is veneer [26]. Details regarding the survey instrument, survey methodology procedures, and data analysis are indicated below.

4.1. Survey Instrument. A 12-page survey was developed covering the topics of timber supply, nature of business, and demographics. This survey was mailed to an extant list of 1,499 logging firms operating in Wisconsin/Upper. Michigan and Indiana in 2004. Logging firms in the study were compiled from government and industry maintained databases of timber buyer and logger training lists. The logging firms were all involved in buying stumpage and/or selling harvested wood. Although the database used in this study was comprehensive, there were likely some logging firms that do not appear on industry-or-agency maintained databases. The survey method utilized was a modified Tailored Design Method [27] with an initial survey mailing followed by a reminder postcard and two follow-up surveys that were sent to nonrespondents. Six hundred ninety-four surveys were returned. However, due to the ineligibility of some respondents, the total number of usable surveys for the analysis was 652 . The overall response rate was $48.5 \%$ which was comprised of a response rate of $59 \%$ for Wisconsin/Michigan and 38\% for Indiana. Due to item nonresponse, the actual " $n$ " will vary by analysis and is indicated in the data tables.

Conceptual variables related in this study were (1) perceptions about the future outlook of the logging industry, (2) profitability of timber sales, (3) source of timber supply, and (4) level of mechanization. The measurement of these conceptual variables is indicated below.

4.2. Variable Measurement. To measure logging industry outlook, a series of 13 questions were asked on the survey relating to this topic. The survey questions examined with factor analysis were the respondent's 5-year outlook on the logging industry. Exploratory factor analysis using Principal Component Analysis (PCA) was used to determine the dimensionality of this 13-question scale in the survey using SPSS 12.0 (Table 1). Factors with eigenvalues greater than one were retained, and Varimax with Kaiser normalization was used to rotate the matrix orthogonally. Two items (logging will stay much like it is and mill prices will increase) were omitted to maximize the scale's Cronbach's alpha. The eleven remaining items loaded onto four factors and explained $56 \%$ of variance in attitudes regarding industry outlook (Table 1). Factor 1 included items related to the challenges faced by the companies. These items include traveling farther for good logging chances, increased stumpage prices, increased competition from outside the United States, and logging will be more regulated. Factor 2 included external urbanization and development items such as decreased logging due to urban sprawl, more woodlots harvested for residential or commercial development, and decreasing size of logging parcels. Items involving the changing nature of logging industry loaded onto Factor 3. These items were trends of logging industry toward fewer, larger logging contractors, more subcontracting with no employees, and becoming more mechanized. Finally, Factor 4 included items relating to lower impact machinery and more regulation.

Factor scores were calculated for each outlook attitude scale using the regression method such that the variables are standardized with a mean of 0 and a standard deviation of 1 [28]. This refined approach is preferable to a coarse approach of summation of items as the refined approach allowed us to incorporate the weighted influence of all items on each of three subscales and created a continuous distribution [28-30]. The mean of all the scales is zero; however, the neutral point of the scale may be above or below the mean as indicated by a positive or negative sign. The benefit of regression scores is that they are continuous variables, each with their own distribution around the common mean of zero. This allows researchers to examine distributions and also makes the variables ideal for use in regression analysis.

Regression factor scores that resulted from the factor analysis were evaluated to determine the percent of individuals that agreed, disagreed, or remained neutral in relation to each factors (Table 2). To determine the neutral score for 
TABLE 1: Rotated component matrix with factor loadings for Logging Industry Outlook Attitude Scale ${ }^{\text {a }}$ Bold indicates factor loadings over 0.40 , contributing most to latent theme of the subscale.

\begin{tabular}{|c|c|c|c|c|}
\hline Verbatim survey items $s^{\mathrm{b}, \mathrm{c}}$ & $\begin{array}{c}\text { Factor } 1 \\
\begin{array}{c}\text { Challenging business } \\
\text { environment }\end{array}\end{array}$ & $\begin{array}{c}\text { Factor } 2 \\
\text { Increasing sprawl } \\
\text { and development }\end{array}$ & $\begin{array}{c}\text { Factor } 3 \\
\text { Changing nature of } \\
\text { business }\end{array}$ & $\begin{array}{c}\text { Factor } 4 \\
\text { More regulation, } \\
\text { low-impact logging }\end{array}$ \\
\hline $\begin{array}{l}\text { Loggers will have to travel further for good logging } \\
\text { chances }\end{array}$ & 0.630 & 0.312 & 0.302 & -0092 \\
\hline Stumpage prices will increase & 0.826 & -0.015 & 0.064 & -0.010 \\
\hline $\begin{array}{l}\text { We will face greater competition from outside the } \\
\text { United States }\end{array}$ & 0.508 & 0.045 & -0.003 & 0.387 \\
\hline $\begin{array}{l}\text { There will be much less logging in my area because } \\
\text { of urban sprawl }\end{array}$ & 0.061 & 0.702 & 0.199 & -0.120 \\
\hline $\begin{array}{l}\text { More woodlots will be harvested for residential or } \\
\text { commercial development }\end{array}$ & -0.077 & 0.748 & -0.012 & 0.100 \\
\hline Logging parcels will be smaller & 0.298 & 0.622 & -0.138 & 0.164 \\
\hline There will be fewer but larger logging contractors & 0.063 & -0.050 & 0.842 & 0.051 \\
\hline $\begin{array}{l}\text { There will be more subcontracting, with no } \\
\text { employees }\end{array}$ & 0.217 & 0.271 & 0.417 & -0.162 \\
\hline Logging will be more mechanized & 0.094 & 0.007 & 0.694 & 0.384 \\
\hline More "low-impact" logging equipment will be used & -0.017 & 0.052 & 0.069 & 0.837 \\
\hline Logging practices will be more regulated & 0.428 & 0.030 & 0.265 & 0.434 \\
\hline
\end{tabular}

${ }^{\mathrm{a}}$ Variance explained $=56.01 \%$; Cronbach's alpha $=0.782, n=613$.

burvey question: please think about what logging will look like in 5 years.

'Scale: 1: strongly disagree; 2: disagree; 3: neither agree nor disagree; 4: agree; 5: strongly agree.

TABLE 2: Factor analysis neutrality results with percent of individuals expressing disagreement, neutrality, and agreement to each factor.

\begin{tabular}{|c|c|c|c|c|c|}
\hline & $\begin{array}{l}\text { Neutral } \\
\text { score }^{\mathrm{a}}\end{array}$ & $\begin{array}{l}\text { Range of } \\
\text { neutrality }\end{array}$ & $\begin{array}{c}\text { \% Individuals expressing } \\
\text { disagreement }\end{array}$ & $\begin{array}{c}\text { \% Individuals within } \\
\text { the Range of } \\
\text { Neutrality }\end{array}$ & $\begin{array}{c}\% \text { Individuals } \\
\text { expressing agreement }\end{array}$ \\
\hline $\begin{array}{l}\text { Factor 1: challenging business } \\
\text { environment }\end{array}$ & -1.843 & -2.371 to -1.315 & $1.0 \%$ & $8.3 \%$ & $90.7 \%$ \\
\hline $\begin{array}{l}\text { Factor 2: increasing sprawl } \\
\text { and development }\end{array}$ & -0.021 & -0.361 to 0.318 & $37.2 \%$ & $27.1 \%$ & $35.7 \%$ \\
\hline $\begin{array}{l}\text { Factor 3: changing nature of } \\
\text { business }\end{array}$ & -0.823 & -1.550 to -0.097 & $6.7 \%$ & $38.3 \%$ & $55.0 \%$ \\
\hline $\begin{array}{l}\text { Factor } 4 \text { : more } \\
\text { regulation/low-impact logging }\end{array}$ & -1.167 & -1.205 to -1.128 & $11.6 \%$ & $1.0 \%$ & $87.4 \%$ \\
\hline
\end{tabular}

${ }^{\text {a }}$ See methodology for calculation procedures.

each subscale, factor scores were calculated based on the existing factor structure for a hypothetical individual who expressed neutral attitudes (response $=3$ ) for all items in each of the subscales. To calculate the range of neutrality, scores on each of the subscales were calculated for two hypothetical individuals who expressed neutral attitudes for every item that dominated (loading of 0.40 or greater) the given subscale with one individual strongly disagreeing (response $=1$ ) with every other item and the other individual strongly agreeing (response $=5$ ) with every other item. These hypothetical scores correspond to the bounds of the conceptual range of neutrality. We used these neutral boundaries to determine the percentage of respondents in our sample who disagreed (i.e., subscale scores fell below the lower bound of neutrality), fell within the range of neutrality, and agreed with each subscale (i.e., subscale scores were above the upper bound of neutrality).

The company's level of harvesting mechanization was determined by the indication of equipment used to harvest or secondarily process timber. If the respondent specified chainsaws as the primary instrument of harvest, they were considered nonmechanized. If the respondent indicated the use of cut-to-length systems, feller-buncher systems, or some combination thereof, they were considered mechanized. To measure profitability, a continuous variable was created that consisted of the proportion of profitable sales as a function of total sales in each acreage category (ratio of the number of total sales in the acreage category divided by the number of profitable sales in the acreage category). We used ANOVA (with Tukey post hoc) to determine whether there was a 
TABLE 3: Relationship between profitability of timber sales of varying sizes by source of timber supply (private family forests).

\begin{tabular}{|c|c|c|c|c|c|c|}
\hline & \multicolumn{2}{|c|}{ Timber sales $^{\mathrm{a}} 1-20$ acres } & \multicolumn{2}{|c|}{ Timber sales $^{\mathrm{a}} 21-80$ acres } & \multicolumn{2}{|c|}{ Timber sales ${ }^{\mathrm{a}} 81+$ acres } \\
\hline & $n$ & $\begin{array}{l}\text { Profitability } \\
\text { ratio }^{\mathrm{a}}\end{array}$ & $n$ & $\begin{array}{l}\text { Profitability } \\
\text { ratio }^{a}\end{array}$ & $n$ & $\begin{array}{l}\text { Profitability } \\
\text { ratio }^{\mathrm{a}}\end{array}$ \\
\hline $\begin{array}{l}\text { Firms with } 0-24 \% \text { of timber supply from } \\
\text { private family forests }\end{array}$ & 33 & 0.59 & 73 & 0.79 & 71 & 0.81 \\
\hline $\begin{array}{l}\text { Firms with } 25-49 \% \text { of timber supply } \\
\text { from private family forests }\end{array}$ & 23 & 0.85 & 45 & 0.79 & 35 & 0.83 \\
\hline $\begin{array}{l}\text { Firms with } 50-74 \% \text { of timber supply } \\
\text { from private family forests }\end{array}$ & 39 & 0.75 & 72 & 0.81 & 41 & 0.76 \\
\hline \multirow[t]{4}{*}{$\begin{array}{l}\text { Firms with } 75-100 \% \text { of timber supply } \\
\text { from private family forests }\end{array}$} & 143 & 0.85 & 206 & 0.89 & 100 & 0.90 \\
\hline & \multicolumn{2}{|c|}{$\begin{array}{c}F=6.276 \\
\mathrm{df}=3\end{array}$} & \multicolumn{2}{|c|}{$\begin{array}{c}F=4.364 \\
\quad \mathrm{df}=3\end{array}$} & \multicolumn{2}{|c|}{$\begin{array}{c}F=2.609 \\
\mathrm{df}=3\end{array}$} \\
\hline & \multicolumn{2}{|c|}{$P<.001$} & \multicolumn{2}{|c|}{$P=.005$} & \multicolumn{2}{|c|}{$P=.05$} \\
\hline & \multicolumn{2}{|c|}{$n=238$} & \multicolumn{2}{|c|}{$n=396$} & \multicolumn{2}{|c|}{$n=247$} \\
\hline
\end{tabular}

${ }^{a}$ Ratio consisting of the number of total sales in the acreage category divided by the number of profitable sales in the acreage category (range is from 0 to 1 ).

significant relationship between timber sale profitability on small, medium, and large timber sales and source of timber supply. We used $t$-tests to determine whether there was a significant relationship between timber sale profitability on small, medium, and large timber sales and level of mechanization.

\section{Results}

5.1. Research Question 1. For attitudes regarding industry outlook, over $90 \%$ of individuals agreed with the items in Factor 1 (challenges) (Table 2). Factor 2 (urbanization and development) had a wider distribution of responses with 36\% agreeing, 27\% neutral, and 37\% disagreeing with its contained items (Table 2). Fifty-five percent of individuals agreed with the items in Factor 3 (changing nature of business), while $38 \%$ remained neutral on these items (Table 2$)$. Finally, the majority $(87 \%)$ of individuals agreed with the items in Factor 4 (low-impact logging and regulation) (Table 2 ).

5.2. Research Question 2. To place the results of the analysis for Research Question 2 in context, we provide descriptive data on the source of timber supply of logging firms in the study region (Figure 1). For private family forestlands, $50 \%(n=314)$ of firms in the study region obtain $75-100 \%$ of their timber supply from this ownership type. About a quarter of firms $(n=149)$ obtain $24 \%$ or less of their timber supply from family forests. Eighty percent of responding logging firms $(n=504)$ indicated that they obtain $24 \%$ or less of their stumpage from industrial lands, while $66 \%$ of responding logging firms $(n=414)$ indicated that they obtain $24 \%$ or less of their timber supply from public lands (federal, state, county). The following results investigate the relationship between source of timber supply, and timber sale profitability among varying parcel sizes.

We found a relationship between profitability of timber sales and source of timber supply and this result is most

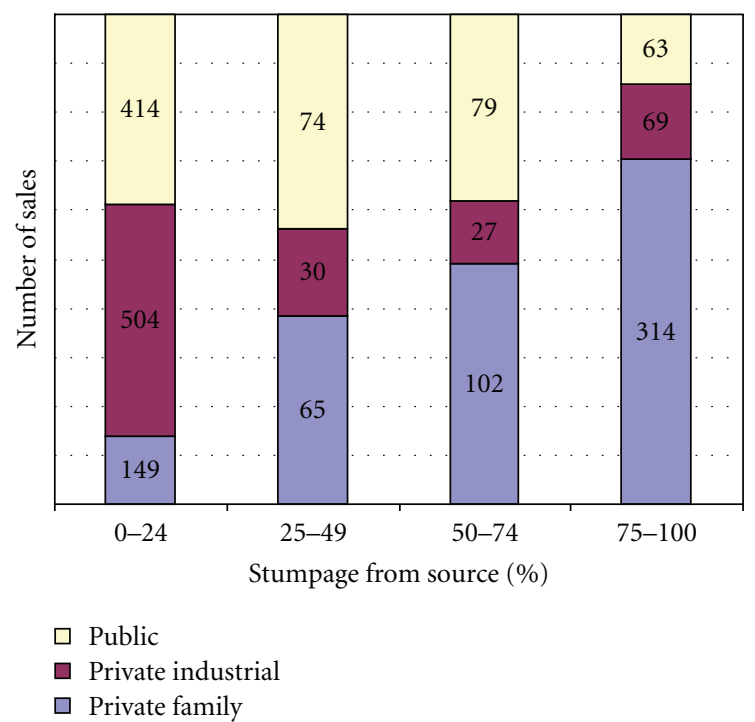

FIGURE 1: Source of timber supply from private family, private industrial, and public forestlands as indicated by firms in the study region.

prominent for those firms that rely on private and public lands versus supply from industrial lands. For small acreage sales (1-20 acres), profitability of those sales was highest for those firms that obtain 25-49\% and 75-100\% of their supply from family forestlands (Table 3 ). The least profitable sales in the small acreage category (1-20 acre harvests) were those who obtained $24 \%$ or less of their supply from private family forests (Table 3). For medium-sized sales (21-80 acres) and large-sized sales $(81+$ acres $)$, those firms that obtained the majority of their supply (75\% or more) from family forests had the highest profitability ratio when compared to firms that drew less of their supply from family forests (Table 3).

There was no significant relationship between industrial sources of timber and profitability of small $(P=.441)$, 
TABLE 4: Relationship between profitability of timber sales of varying sizes by source of timber supply (public forests).

\begin{tabular}{|c|c|c|c|c|c|c|}
\hline & \multicolumn{2}{|c|}{ Timber sales $1-20$ acres } & \multicolumn{2}{|c|}{ Timber sale $21-80$ acres } & \multicolumn{2}{|c|}{ Timber sales $81+$ acres } \\
\hline & $n$ & $\begin{array}{c}\text { Profitability } \\
\text { ratio }^{\mathrm{a}}\end{array}$ & $n$ & $\begin{array}{c}\text { Profitability } \\
\text { ratio }^{\mathrm{a}}\end{array}$ & $n$ & $\begin{array}{c}\text { Profitability } \\
\text { Ratio }^{\mathrm{a}}\end{array}$ \\
\hline Firms with $0-24 \%$ of timber supply from public forests & 166 & 0.85 & 257 & 0.88 & 149 & 0.86 \\
\hline Firms with $25-49 \%$ of timber supply from public forests & 33 & 0.70 & 53 & 0.83 & 37 & 0.81 \\
\hline Firms with $50-74 \%$ of timber supply from public forests & 22 & 0.68 & 52 & 0.75 & 27 & 0.74 \\
\hline \multirow[t]{4}{*}{ Firms with $75-100 \%$ of timber supply from public forests } & 17 & 0.58 & 34 & 0.75 & 34 & 0.88 \\
\hline & \multicolumn{2}{|c|}{$\begin{array}{c}F=5.969 \\
\mathrm{df}=3\end{array}$} & \multicolumn{2}{|c|}{$\begin{array}{c}F=4.757 \\
\mathrm{df}=3\end{array}$} & \multicolumn{2}{|c|}{$\begin{array}{c}F=1.424 \\
\mathrm{df}=3\end{array}$} \\
\hline & \multicolumn{2}{|c|}{$P=.001$} & \multicolumn{2}{|c|}{$P=.003$} & \multicolumn{2}{|c|}{$P=.236$} \\
\hline & \multicolumn{2}{|c|}{$n=238$} & \multicolumn{2}{|c|}{$n=396$} & \multicolumn{2}{|c|}{$n=247$} \\
\hline
\end{tabular}

${ }^{a}$ Ratio consisting of the number of total sales in the acreage category divided by the number of profitable sales in the acreage category (range is from 0 to 1 ).

TABLE 5: Relationship between mechanization and profitability of timber sales of varying sizes.

\begin{tabular}{|c|c|c|c|c|c|c|}
\hline & \multicolumn{2}{|c|}{ Timber sales $1-20$ acres } & \multicolumn{2}{|c|}{ Timber sales $21-80$ acres } & \multicolumn{2}{|c|}{ Timber sales $81+$ acres } \\
\hline & $n$ & $\begin{array}{c}\text { Profitability } \\
\text { ratio }^{\mathrm{a}}\end{array}$ & $n$ & $\begin{array}{c}\text { Profitability } \\
\text { ratio }^{\mathrm{a}}\end{array}$ & $n$ & $\begin{array}{c}\text { Profitability } \\
\text { ratio }^{\mathrm{a}}\end{array}$ \\
\hline Mechanized & 137 & 0.73 & 243 & 0.82 & 171 & 0.85 \\
\hline Non-mechanized & 101 & 0.88 & 152 & 0.88 & 76 & 0.82 \\
\hline & \multicolumn{2}{|c|}{$F=13.204$} & \multicolumn{2}{|c|}{$F=4.553$} & \multicolumn{2}{|c|}{$F=0.482$} \\
\hline & \multicolumn{2}{|c|}{$\mathrm{df}=1$} & \multicolumn{2}{|c|}{$\mathrm{df}=1$} & \multicolumn{2}{|c|}{$\mathrm{df}=1$} \\
\hline & \multicolumn{2}{|c|}{$P<.001$} & \multicolumn{2}{|c|}{$P<.05$} & \multicolumn{2}{|c|}{$P=.488$} \\
\hline & \multicolumn{2}{|c|}{$n=237$} & \multicolumn{2}{|c|}{$n=394$} & \multicolumn{2}{|c|}{$n=246$} \\
\hline
\end{tabular}

${ }^{a}$ Ratio consisting of the number of total sales in the acreage category divided by the number of profitable sales in the acreage category (range is from 0 to 1 ).

medium $(P=.499)$, or large $(P=.246)$ timber sales. For public lands, significant differences were observed in both small (1-20 acres) and medium-sized sales but not on larger sales ( $81+$ acres) (Table 4$)$. For both small- and mediumsized timber sales, firms that obtained $24 \%$ or less of their supply from public lands had the most profitable sales (Table 4).

5.3. Research Question 3. Level of mechanization for firms was varied with 59\% of firms utilizing chainsaw-based systems and 41\% employing a greater level of harvesting technology (feller-bunchers, cut-to-length, forwarders, and harvesters). Nonmechanized firms have a significantly higher profitability ratio on small-(1-20 acres) and medium-(2180 acres) sized sales compared to their mechanized counterparts (Table 5). On the largest sales ( $81+$ acres), there were no significant differences between mechanized and nonmechanized firms; they were both profitable on upwards of $80 \%$ of timber sales in this size category. The lowest profitability ratio was 0.73 for mechanized harvests on 1-20 acres, and the highest profitability was reported on small- to medium-sized nonmechanized harvests ( 80 acres or less).

\section{Discussion}

Most firms in this study agreed that the logging industry is facing challenges related to the business environment (increasing stumpage prices, having to travel further for good logging chances, greater competition from outside the United States, and more regulated practices, greater use of low-impact logging systems). However, logging firms were split on their views toward the effects related to increasing sprawl and development with $36 \%$ agreeing that this will be a concern in the short term and a nearly equal number of respondents $(37 \%)$ disagreeing. Slightly over half of respondent logging firms felt that the logging business 5-year outlook will include fewer but larger logging contractors, more subcontracting, and more mechanized logging. In terms of attitudes, firm owners did not universally view urbanization and parcelization issues as significant issues facing their businesses.

Logging firms in the north central region rely heavily on private family forests with half of the responding firms indicating that they obtain a majority (75\% to $100 \%)$ of their stumpage from this source. Firms in the study region were less reliant on public and industrial lands as sources of timber which are less abundant than private nonindustrial forests in the region.

Generally, profitability of timber sale increased with size of timber sale. For public lands, profitability only varied on small and medium sized timber sales. Profitability of timber sales actually decreased with strong reliance on public lands as a source of timber on small timber sales. These small sales were less profitable on public lands. For medium-sized sales 
on public lands, profitability also decreased with a reliance on public forests for a majority of timber supply $(50 \%$ or more). Small timber sales, regardless of the dependency mix, were the least profitable on public forest lands. Firms in the study were better able to harvest small tracts profitably on private lands. Those firms that draw a significant source of their supply from private forestlands (25\% or more) were able to maintain a higher profitability threshold (75$85 \%$ of sales were profitable) than those that relied less on private lands less as a source of timber. For private industrial lands, no significant differences in profitability were observed regardless of timber sale size and reliance on these lands for harvest.

Mechanization is related to profitability on small and medium timber sales. Nonmechanized firms were significantly better able to conduct timber sales profitability on small-(20 acres or less) and medium-sized (21-80 acres) harvests compared to their mechanized counterparts. On larger timber sales ( 81 acres or more), mechanization did not have a significant relationship with profitability. Consistent with Rickenbach and Steele [21], we found that some firms are specializing and adapting to harvesting small tracts profitably. The mechanization trends coupled with ownership dynamics makes the issue of parcelization more prevalent as it impacts private lands to a greater extent than public lands.

Not all firms are adopting the changes in harvest technology as a proportion of firms are remaining nonmechanized in their harvesting methods and machinery. It is these lessmechanized firms that are better able to harvest smalland medium-sized tracts profitably. This is likely insulating them, in part, from the parcelization trends identified in the literature review of this paper. In fact, nonmechanized firms may have somewhat of an advantage on smaller tracts. As the practice of forestry moves more toward a "boutique" model [10], nonmechanized firms will be an essential piece of that puzzle, giving smaller landowners a profitable and less-intensive option for harvesting. Also, as forestland parcelization continues, it may produce greater demand for logging services on small parcels of land. Thus, logging firms may adapt their services, equipment, and fee structure to conduct profitable harvests on small parcels of woodland. Thus, parcelization may not necessarily lead to a negative outcome for all loggers-especially if some are able to adapt to changing landscape conditions by altering their services, equipment, and outlook to remain profitable.

\section{References}

[1] S. A. Sinclair, C. C. Hassler, K. Bolstad, and E. Kallio, "Characteristics of independent loggers: productivity, employees, profitability," Forest Products Journal, vol. 35, no. 5, pp. 19-24, 1985.

[2] M. Rickenbah, T. Steele, and M. Shira, Status of the Logging Sector in Wisconsin and Michigan's Upper Peninsula, University of Wisconsin Extension, Woodruff, Wis, USA, 2003.

[3] C. Best and L. A. Wayburn, America's Private Forests, Island Press, Washington, DC, USA, 2001.
[4] D. J. Nowak and J. T. Walton, "Projected urban growth (20002050) and its estimated impact on the US forest resource," Journal of Forestry, vol. 103, no. 8, pp. 383-389, 2005.

[5] D. N. Wear, R. Liu, J. M. Foreman, and R. M. Sheffield, "The effects of population growth on timber management and inventories in Virginia," Forest Ecology and Management, vol. 118, no. 1-3, pp. 107-115, 1999.

[6] W. D. Greene, T. G. Harris Jr., C. E. DeForest, and J. Wang, "Harvesting cost implications of changes in the size of timber sales in Georgia," Southern Journal of Applied Forestry, vol. 21, no. 4, pp. 193-198, 1997.

[7] C. Woodall, D. Johnson, J. Gallion et al., Indiana's Forests 1999-2003 (Part A), USDA Forest Service NC-253A, Saint Paul, Minn, USA, 2005.

[8] C. W. Toms, M. R. Dubois, J. C. Bliss, J. H. Wilhoit, and R. B. Rummer, "A survey of animal-powered logging in Alabama," Southern Journal of Applied Forestry, vol. 25, no. 1, pp. 17-24, 2001.

[9] L. A. DeCoster, "The boom in forest owners-a bust for forestry?" Journal of Forestry, vol. 96, no. 5, pp. 25-28, 1998.

[10] R. B. Hull, D. P. Robertson, and G. J. Buhyoff, "Boutique forestry: new forest practices in urbanizing landscapes," Journal of Forestry, vol. 102, no. 1, pp. 14-19, 2004.

[11] P. H. Gobster and M. G. Rickenbach, "Private forestland parcelization and development in Wisconsin's Northwoods: perceptions of resource-oriented stakeholders," Landscape and Urban Planning, vol. 69, no. 2-3, pp. 165-182, 2004.

[12] B. C. Butler, E. C. Leatherberry, C. Best, M. A. Kilgore, R. N. Sampson, and K. Larson, "America's family forest owners," Journal of Forestry, vol. 102, no. 7, pp. 4-9, 2004.

[13] F. W. Cubbage, "Economics of forest tract size: theory and literature," Forest Service General Technical Report SO-GTR41, 1983.

[14] F. W. Cubbage and J. W. Davis, "Historical and regional stumpage price trends in Georgia," Forest Products Journal, vol. 36, no. 9, pp. 33-39, 1986.

[15] C. Row, "Economics of trace size and growing timber," Journal of Forestry, vol. 76, no. 9, pp. 576-582, 1978.

[16] T. J. Straka, H. W. Wisdom, and J. E. Moak, "Size of forest holding and investment behavior of nonindustrial private owners," Journal of Forestry, vol. 82, no. 8, pp. 495-496, 1984.

[17] J. Romm, R. Tuazon, and C. Washburn, "Relating forestry investment to the characteristics of nonindustrial private forestland owners in northern California," Forest Science, vol. 33, no. 1, pp. 197-209, 1987.

[18] K. K. Edwards and J. C. Bliss, "It's a neighborhood now: practicing forestry at the urban fringe," Journal of Forestry, vol. 101, no. 3, pp. 6-11, 2003.

[19] W. D. Greene, F. W. Cubbage, and J. F. McNeel, "Characteristics of independent loggers in Georgia," Forest Products Journal, vol. 38, no. 7-8, pp. 51-56, 1988.

[20] M. Rickenbach and T. W. Steele, "Logging firms, nonindustrial private forests, and forest parcelization: evidence of firm specialization and its impact on sustainable timber supply," Canadian Journal of Forest Research, vol. 36, no. 1, pp. 186194, 2006.

[21] M. Rickenbach and T. W. Steele, "Comparing mechanized and non-mechanized logging firms in Wisconsin: implications for a dynamic ownership and policy environment," Forest Products Journal, vol. 55, no. 11, pp. 21-26, 2005.

[22] D. S. Powell, J. L. Faulkner, D. R. Darr, Z. Zhu, and D. W. MacCleery, "Forest resources of the United States," General 
Technical Report RM-234, USDA Forest Service Rocky Mountain Forest and Range Experiment Station, Fort Collins, Colo, USA, 1992.

[23] M. J. Keefer, J. C. Finley, A. E. Luloff, and M. E. McDill, "Understanding loggers' perceptions," Journal of Sustainable Forestry, vol. 17, no. 3, pp. 81-102, 2003.

[24] I. A. Munn, J. B. Cutshall, and D. G. Hodges, "1993 pulpwood logging contractor survey," Forest Products Journal, vol. 48, no. 7-8, pp. 47-53, 1998.

[25] W. G. Luppold, C. C. Hassler, and S. Grushecky, "An examination of West Virginia's logging industry," Forest Products Journal, vol. 48, no. 2, pp. 60-64, 1998.

[26] S. R. Shifley and N. H. Sullivan, "The status of timber resources in the North Central United States," USDA Forest Service NC-GTR-228, 2002.

[27] D. A. Dillman, Mail and Internet Surveys: The Tailored Design Method, John Wiley \& Sons, New York, NY, USA, 2nd edition, 2000.

[28] J. W. Grice, "Computing and evaluating factor scores," Psychological Methods, vol. 6, no. 3, pp. 430-450, 2001.

[29] K. A. Schaaf, A. L. Ross-Davis, and S. R. Broussard, "Exploring the dimensionality and social bases of the public's timber harvesting attitudes," Landscape and Urban Planning, vol. 78, no. 1-2, pp. 135-146, 2006.

[30] K. A. Schaaf and S. R. Broussard, "Private forest policy tools: a national survey exploring the American public's perceptions and support," Forest Policy and Economics, vol. 9, no. 4, pp. 316-334, 2006. 

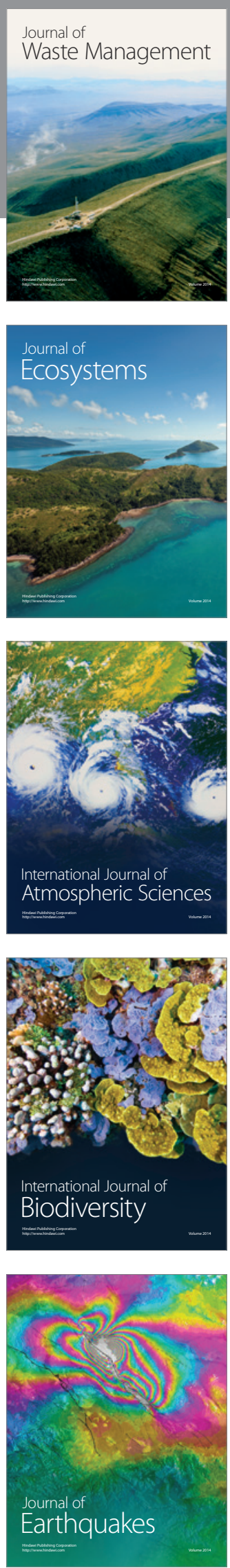
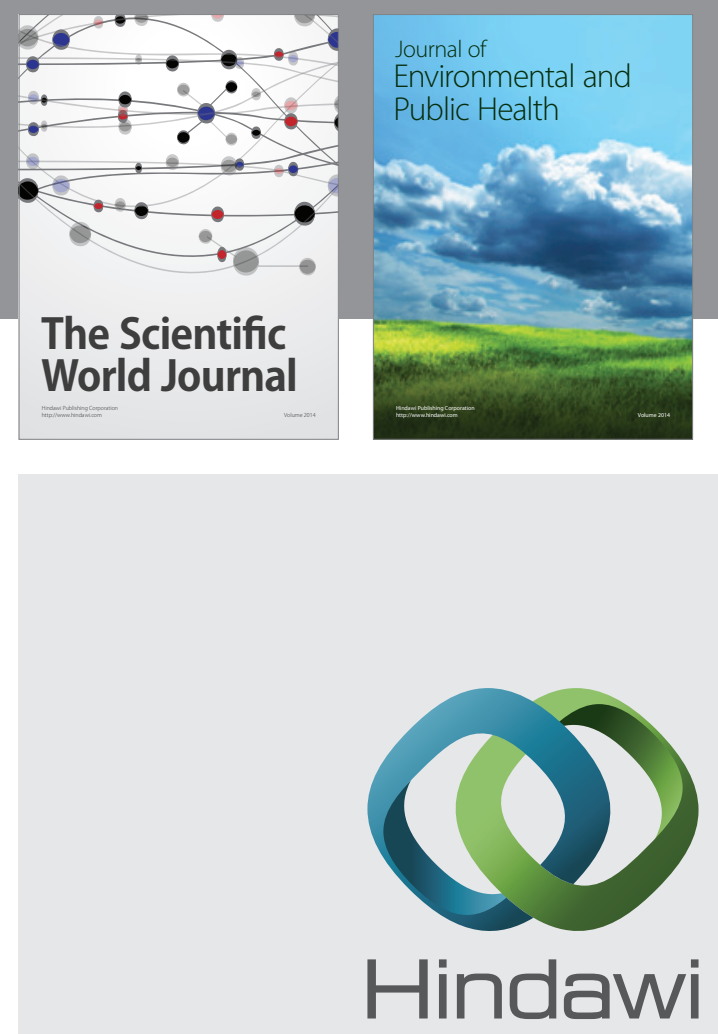

Submit your manuscripts at

http://www.hindawi.com
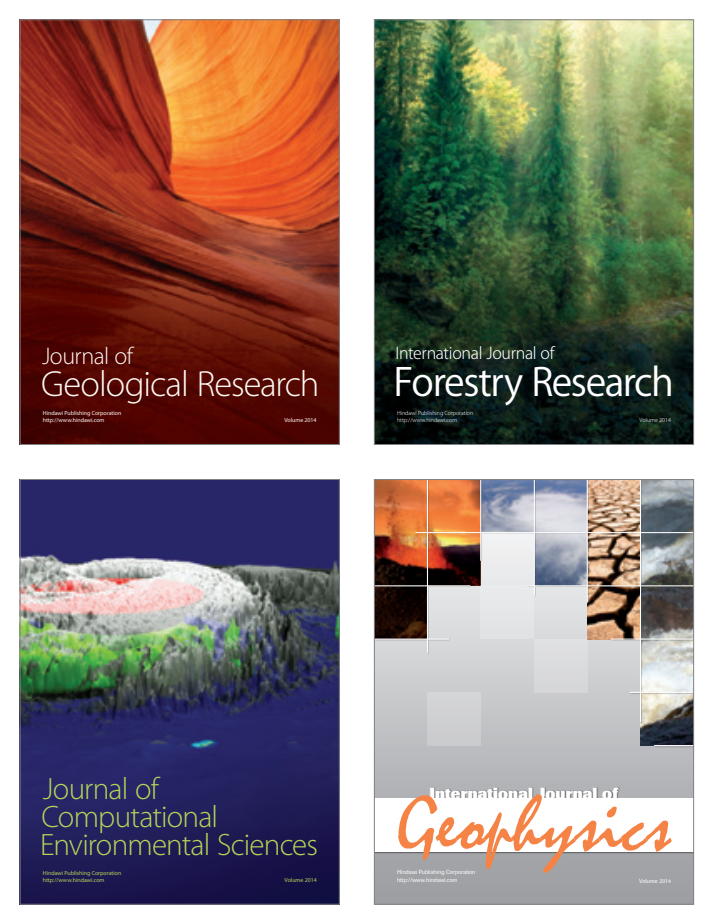
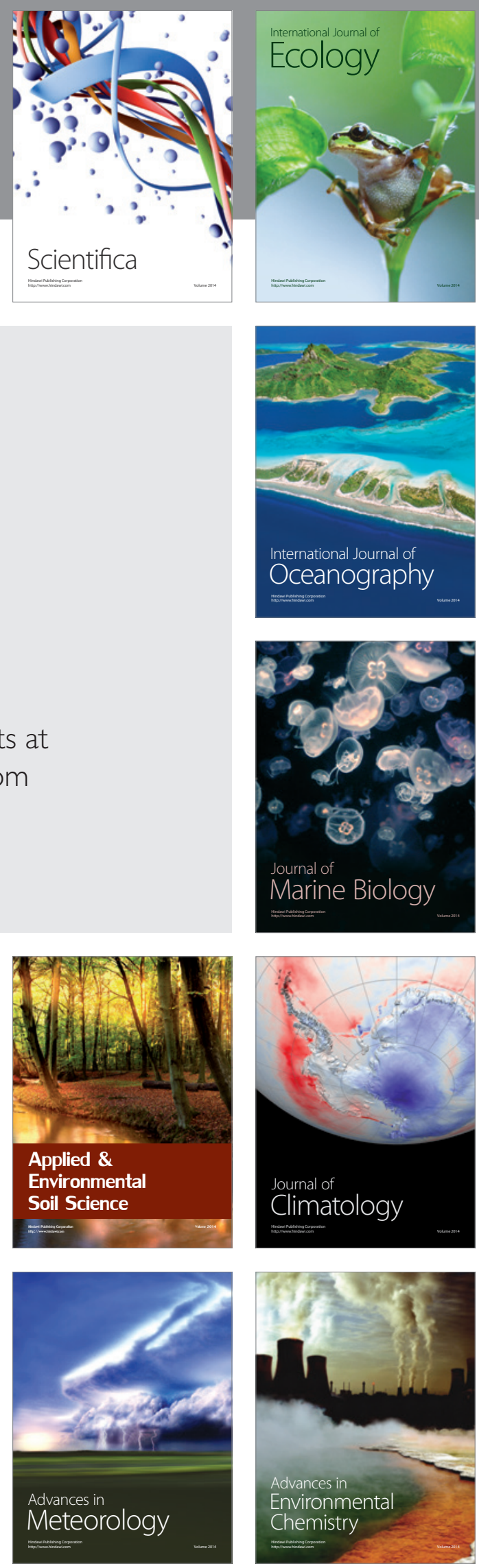